\title{
ロボットハンドのための 指紋を備えた高周波微振動検出式滑り覚センサ†
}

\author{
山田陽 滋*·森 田裕 之*・梅 谷 陽 二**
}

A Slip Sensor with Surface Ridges Which is Mounted on a Robot Hand

Generates High-Frequency Signals for Isolating Slip Phases ${ }^{\dagger}$

Yoji YAMAdA*, Hiroyuki MoRita* and Yoji UMEtani*

\begin{abstract}
This paper deals with a slip sensor that has ridges on the sensor surface and is capable of isolating a slip phase from other contact states between an object and the sensor surface, which has not been verified by using conventional slip sensors. The proposed structure of the sensor enables it to detect high-frequency slip vibration with vertically molded strip-shaped ridges of the sensor, in each of which a piece of PVDF film is fixed. We were convinced through wavelet analysis that the vibration corresponded to a free vibration mode of the strip-shaped ridges and that the vibration did not depend upon the surface condition. We showed that the slip sensor generated a slip signal which was characterized by distinction of only slip phases from other contact, release, or roll phases. Especially, the last two phases could be discriminated by the characteristic waveform of release-phase overshoot. The sensor output signal was also shown to be very different from the noise signal which originated in the vibration caused by driving a motor of the experimental setup. Finally, we demonstrated that a two-fingered planar robot hand successfully arrested a slipped-off notebook using the distinctive slip information acquired from the sensor after the necessity of detecting not an incipient but a total slip phase.
\end{abstract}

Key Words: slip sensor, ridge, high-frequency vibration, wavelet analysis, release-phase overshoot

\section{1.はじめに}

ロボットフィンガ表面上を物体が滑るときに発生する滑り 情報の検出手法が上田ら ${ }^{1)}$ によって初めて示されて以来, こ れまでに様々な滑り覚センサが報告されてきた ${ }^{2)}$. 特に, 近 年主流である柔軟被覆をもつロボットフィンガによる物体把 持の場合, フィンガ表面を物体が滑っている, あるいは滑っ ていない, という状態を, トライボロジーの観点 ${ }^{3)}$ から識別 することができるスティック・スリップ (以下, stick-slip と 記す）振動の検出アプローチは，現象論的にも，また滑りの 検出感度の点でも非常に有効であると考えられる。しかしな がら,この stick-slip 振動が物体の安定把持に関わる滑り検 出に有用であるとする提案 ${ }^{4)}$ がなされて十余年を経たにもか かわらず, 滑り信号をフィードバック情報として活用した口 ボットハンドによる実時間的な物体の把持・操り制御に著し い技術的進展が認められない。その主な理由の一つは，これ

† 日本ロボット学会第 3 回ロボティクス・シンポジア $(1998 \cdot 5)$, 第 17 回学術講演会 $(1999 \cdot 9)$ で発表

* 豊田工業大学大学院工学研究科 名古屋市天白区久方 2-12-1

* Graduate School of Toyota Technological Institute, 2-12-1 Hisakata, Tempaku-ku Nagoya

(Received August 26, 1999)

(Revised February 3, 2000)
までに報告された滑り覚センサは，物体が滑るときにのみ情 報を与えるという機能が保証されていなかったことによる． すなわち, 物体とフィンガの接触状態としては, 滑りの状態 の他に, 物体の接触の瞬間, 転がりの状態, そして, 解放の 瞬間があるが, このような様々な接触状態のうち, 滑り状態 に対してだけ出力を与えるという厳密な意味での滑り検出の 報告がなされたことはこれまでになかったのである．現に， 滑りを, 上述の他の接触状態や, さらにフィンガのアクチュ エーションに伴って発生する機械的振動ノイズと実時間的に 識別することの困難さはすでに指摘されているところであ る5).このような滑り覚センシング技術の現状に対し, 本研 究では物体の滑りを教える情報源として, stick-slip 信号で はなくさらに高周波の振動信号成分に着目する.

さて, ゴムの摩擦メカニズムを詳細に追求する研究におい て,ゴム表面では slip 時に, ゴム材料の表面物性值に依存し た固有振動数をもつ高周波微振動が生じているという現象が 報告されている6)。これを手がかりとして，センサ表面に凹 凸を形成しておき, 物体が表面上を滑る際の凸部の自由振動 を高感度に検出できるようにすることにより，滑りに固有の 情報が取得できることを突き止めた。

本論文では, 従来の滑り覚センサの開発報告では厳密に議 論されることのなかった重要な観点として,「滑り状態のみを 
検知する機能」を取り上げ，これを達成することができるセ ンサ7)をあらためて滑り覚センサとして提案する。まず第 2 節において高周波微振動を生じるために指紋を設けたセンサ の構造とセンサ信号増幅回路を表す。つぎに第 3 節では，提 案する検出対象である高周波微振動が，指紋の自由振動によ るものであると結言できることを，それに至る評価解析内容 と共に示す，そして第 4 節では，滑り以外の接触状態に対す るセンサ出力信号の様子を主に報告し，その中に，滑り以外 の接触状態が，滑り状態と明確に区別される情報を含んでい ることを示す。さらに第 5 節では，ロボットハンドに実際に 滑り覚センサを取り付けて物体を把持させ，滑り覚情報に基 づいた物体の滑り抑止制御を達成することにより，提案する センサの有用性を実験的に確認する。最後の第 6 節で本研究 に関する結果のまとめと今後の課題を述べる。

\section{2. 滑り覚センサ}

\section{1 滑り覚センサの構造}

Fig.1に，本論文で筆者らが提案するセンサの構造を示す. このセンサは, 同図中右に示す座標系の X 軸方向の滑りを検 出する，その滑りを高感度に検出するために，Y 方向に溝を 施して凹凸形状にし，振動を起こしやすくしている，センサ を構成しているシリコンゴム（ヤング率 $=1.8 \times 10^{3} \mathrm{MPa}$ ，ポ アソン比 $=0.495 ）$ の表面は, 断面が 2 種類の凸形状を呈す る部分から構成されている。それぞれの寸法は幅の広い凸部 の方が $5 \mathrm{~mm} \times 1.5 \mathrm{~mm}$ ，幅の狭い凸部（以下適宜，指紋凸部 と呼ぶ）の方は $1 \mathrm{~mm} \times 1.5 \mathrm{~mm}$ であり，両者の間隔は $1.5 \mathrm{~mm}$ となっている、これらのうち，指紋凸部には，短冊状で外形 寸法が $10 \mathrm{~mm} \times 2 \mathrm{~mm}$ の PVDF フィルムを，XY平面に垂 直に立ててその長手方向が $\mathrm{Y}$ 軸に添うように埋め込んであ る．応力に比例した電荷を発生するトランスデューサとして のPVDF フィルム ${ }^{8), 9)}$ の両面それぞれに, シールド線が銀 ペーストによって接続（その後，瞬間接着剤で固定）され， 次段の差動増幅器へと接続されている. Son ら ${ }^{10)}$ は, シリコ ンゴム材のフィンガ表面全体に細長い突起を成形によって分 布状に配置し，滑りによって突起が振動することを検出しよ うとしている。この形状は，筆者らの場合と同様にセンサの 感度を向上させようとするものだが, 報告されているセンサ 出力は低周波で滑りに固有のものであるかどうかは不明であ り,さらに，このような突起形状ではロボットフィンガで物 体を把持しようとするときには静止摩擦力の減小によって把 持の安定性が損なわれる可能性がある。これと比較して筆者 らのセンサは, PVDF フィルムを埋め込んである振動を検出 するための指紋凸部を極めて薄くすることによって，振動に 対する感度の向上を図り, さらにその両側に比較的幅の広い 平坦部を備えることによって把持力低下につながる静止摩擦 力の低下を抑止している.

\section{2 センサ信号増幅回路}

次に, センサの出力信号を得るための増幅回路を Fig.2に 示す。この回路は, オペアンプの差動増幅を利用したもので

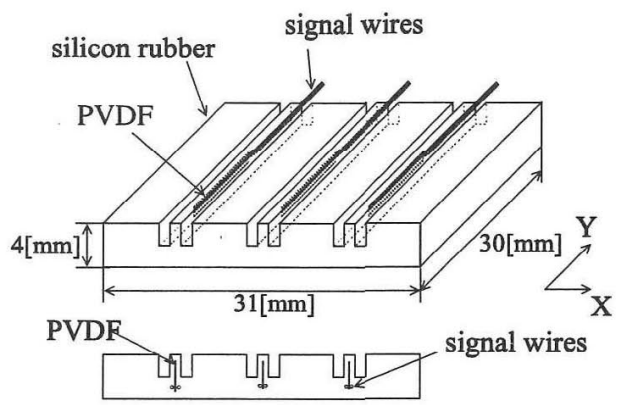

Fig. 1 Structure of the slip sensor

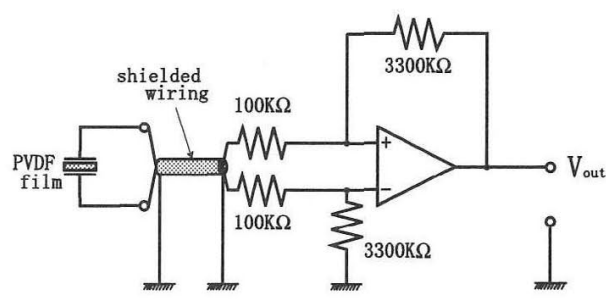

Fig. 2 Circuit diagram for amplifying the sensor signals transduced by the PVDF film

ある．この差動増幅により，PVDF や信号線に重畳する外界 の同相ノイズが除去できることが大きな特徵となっている. このため, 商用電源周波数成分等の電磁ノイズを除去するた めのフィル夕を設ける必要はなくなり，センサからの出力を より忠実に再現できる。本論文では，以下，3.2節以降 4節 まで，および 5.2節では, Fig.1のセンサ表面右端のチャネル \#1の出力信号を，また，5.1節では，3チャネル全ての出力 信号を対象として議論を進める。

\section{3. 滑り覚センサの挙動およびセンサ出力の評価}

本節では，前節で述べた滑り覚センサを用いて物体の滑り 実験を行う際に得られるセンサ出力信号と，センサの指紋凸 部の挙動とを比較することによって，この信号がどのような 現象を示しているかを判断する。

\section{1 指紋凸部の力学的挙動とセンサ出力の関係}

まず，センサの指紋凸部がどのような力学的挙動を伴うか を調べるために，実験で用いたセンサを Fig.3に示す。この センサは，Fig.1で示したセンサ表面の幅の広い凸部を取り除 いた構造となっており，材料は同じである。この実験の場合 のセンサの指紋凸部（以下，凸部単体と呼ぶ）を弾くことに よって，自由振動を発生させる，凸部単体の自由振動時の運 動は，Fig.4に示すように，その速度や加速度をレーザドッ プラ振動計（Minato Electronics Inc., model 6410A）を用 いて計測することにより調べる。センサとドップラ振動計と もに，外的な振動の影響を受けないように実験環境に注意を 払った.

このような実験環境のもとで行った実験結果を Fig.5と Fig.6に示す．Fig.5は，凸部単体を弾いたときに生じる自由 


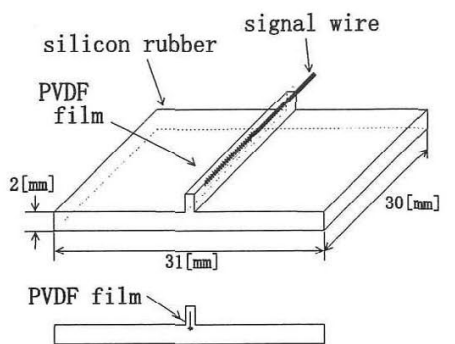

Fig. 3 Structure of the one-element slip sensor

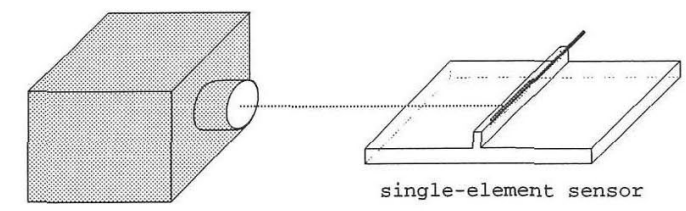

laser doppler vibrometer

Fig. 4 Illustration of the experimental setup for detecting the free vibration

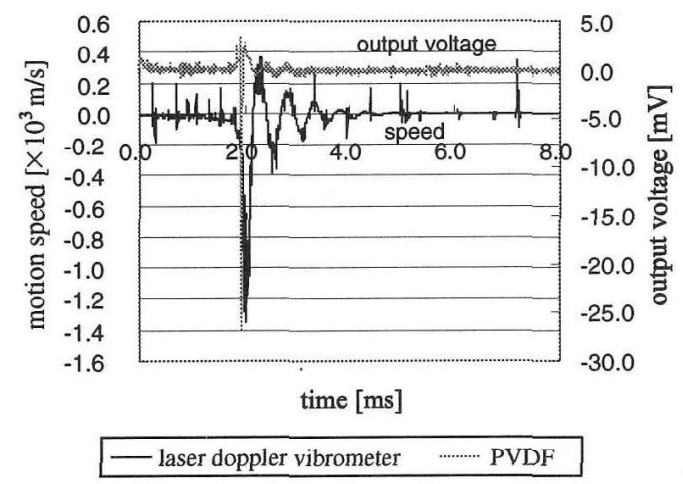

Fig. 5 Comparison of waveforms between the sensor output and the vibration speed of the sensor ridge

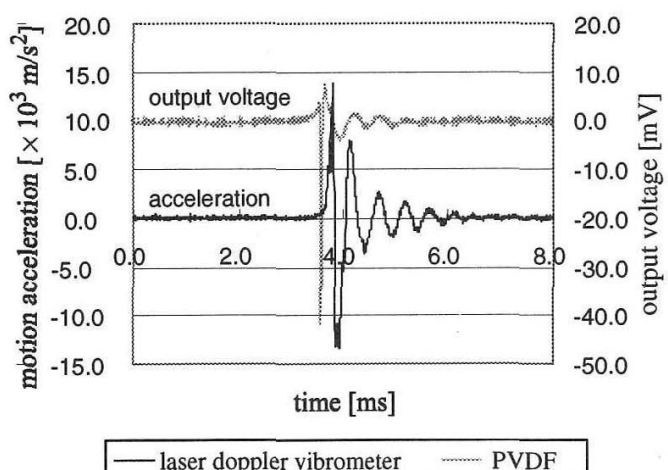

Fig. 6 Comparison of waveforms between the sensor output and the vibration acceleration of the sensor ridge

振動の速度をドップラ振動計で計測した結果とセンサ出力を 合わせて示したものである.このように, 凸部単体の速度と センサ出力はともに減衰振動しており，それぞれの減衰振動 周波数は $2.15 \mathrm{kHz}$ と $2.39 \mathrm{kHz}$ と近い值となっている.この 結果からセンサ出力は, 凸部単体の自由振動に相当すると考
える、ただしセンサ出力のはじめの波形は，減衰振動とは異 なり大きく鋭角な波形で, この点で凸部単体の速度と異なっ た結果を示している。またFig.6は，同様に凸部単体の加速 度をドップラ振動計で計測した結果とセンサ出力である。凸 部単体の加速度もセンサ出力も, ともに減衰振動を呈し, そ の周波数は $2.05 \mathrm{kHz}$ と一致している。この結果は再び, セン サ出力が自由振動に対応していることを示している。 それに 加え, 加速度の波形は立ち上がりが速く, 速度の波形よりも センサ出力に似た波形となっている.

以上の結果から, 凸部単体は減衰する自由振動を行い, そ の振動をセンサ出力として得ることができた。 またセンサ出 力は, 速度よりも加速度としての特性を示すこともわかった。

\section{2 評価装置および滑り実験とその結果}

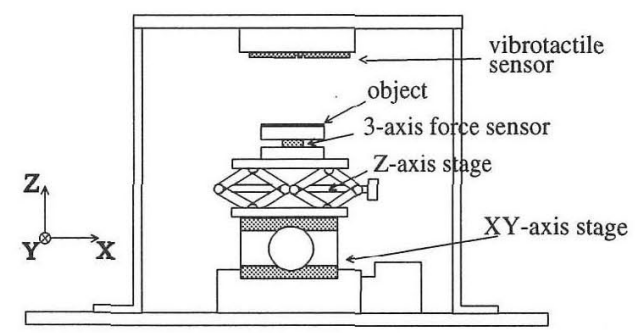

Fig. 7 Experimental setup for evaluating the slip sensing performance with high repeatability

Fig.7に, 物体の滑り実験を行うための評価装置を示す。こ の評価装置は, 大きく分けてセンサを固定するためのアーチ 状の取り付け部と, 把持物体と仮定した対象物体を滑らせる ための XY ステージで構成されている．XY ステージは，ス テッピングモータにより, X, Y 各軸方向に動かすことがで き, その上に Z 軸方向に高さを調節する Z ステージがある. さらにその上に, $\mathrm{Z}$ 軸方向の力を計測できる力覚センサ（日 本キスラー製，9251A）を設けている。この力覚センサを用 い，ロボットハンドでの把持力に相当する $\mathrm{Z}$ 軸方向の力成分 を検出する。滑り覚センサは, 粘弾性体であるシリコンゴム で作られているため, 滑り覚センサ表面に加わった力は, そ の底面に伝わるまでに時間遅れを生じる。これを考慮して, 滑り覚センサ表面にかかる力を精確に計測する目的で対象物 体の下に配置した。

評価する滑り覚センサは，X 軸方向の滑りを検出するので, $\mathrm{XY}$ ステージを X 軸方向に動かし, その際にセンサから出力 される信号を捉えるとともに, 適宜, 力覚センサの出力を求 めて比較する.

滑り覚センサの評価として, まず表面に凹凸のある場合と 無い場合の静止摩擦係数を比べた結果, その差は最大で約 0.02 であった。この差は凹凸の無い場合の静止摩擦係数の最 大で $5 \%$ と低く，形状による影響がほとんど見られない。す なわち接触面積の減小は, 物体の把持・操りに対して影響を 与えないと考える。

つぎに, Fig.7に示す評価装置を用い, 滑り振動の発生な らびに評価実験を行ったときのセンサ出力信号例を以下に示 

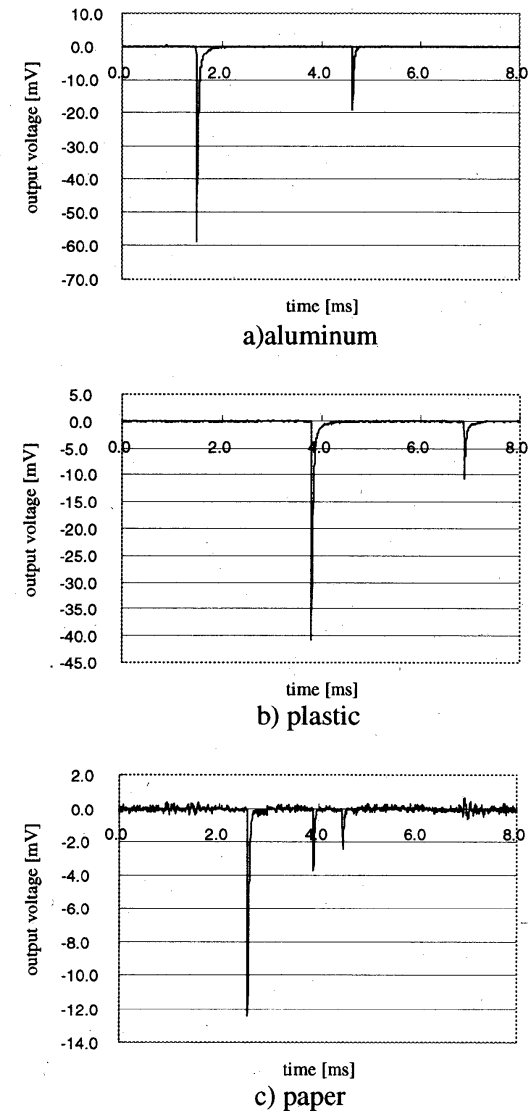

Fig. 8 Samples of the slip sensor outputs for various kinds of object surface

す. 実験条件として, 対象物体を $16 \mathrm{~mm} / \mathrm{s}$ で $\mathrm{X}$ 軸方向に動 かし， Z 軸方向の押し付け力は $0.75 \mathrm{kPa}$ である.

Fig.8の a）は対象物体としてアルミを用いたときの滑り 覚センサの出力, Fig.8のb) ではプラスチックを用いたと きのセンサ出力, Fig.8の c) ではコピー用紙を用いたとき のセンサ出力をそれぞれ表している。このように対象物体が アルミでもコピー用紙でもプラスチックでも，インパルス状 のセンサ出力が得られることを確認した. 他方, このセンサ は，センサ表面と対象物体がずれただけで, stick状態にある ときは何も出力しない.

\section{3 実験結果の解析}

Fig.8に示したインパルス状の信号は, 主インパルスに続 く減衰状の振動こそ見られないものの，3.1節に表した指紋 凸部を弾いたときのセンサ出力と似ている。 そこで, 3 種の 対象物体の滑りに対するセンサ出力と，3.1節で表した凸部 単体の自由振動の関係についてさらに詳しく調べる.

滑りのときに発生するセンサ出力が指紋凸部の自由振動で あるとすれば，両者に何らかの類似点があるはずである。そ こでセンサ出力信号に対しウェーブレット変換を行うことに よって, 時間一周波数の 2 次元領域でそれぞれの信号を解析す る. 変換結果を Fig.9に示す．この変換には, $\operatorname{Symlet}(\mathrm{N}=8)$ を用いた。 a) 図は Fig.6に示す凸部単体の自由振動時の，ま た，b)，c)，d）はそれぞれ Fig.8に示した対象物体（アルミ,

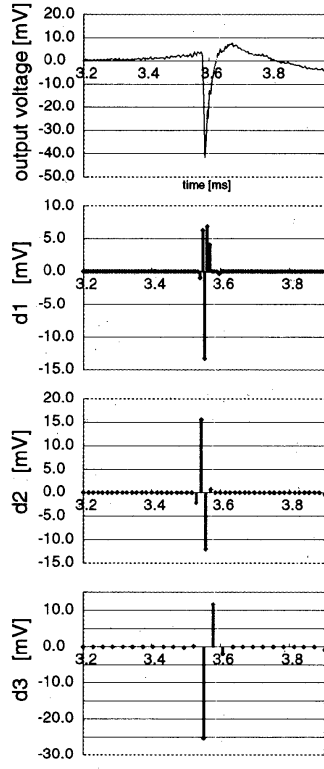

a) free vibration
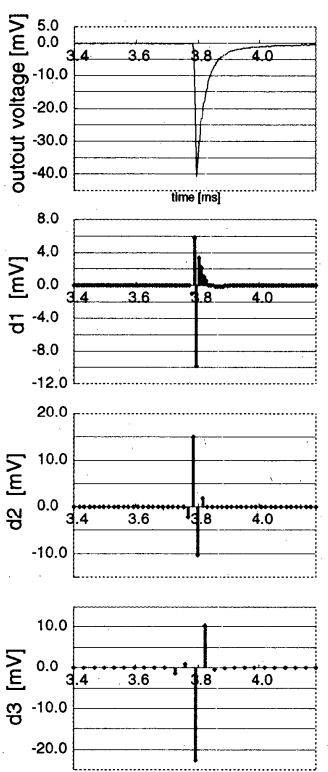

c) plastic
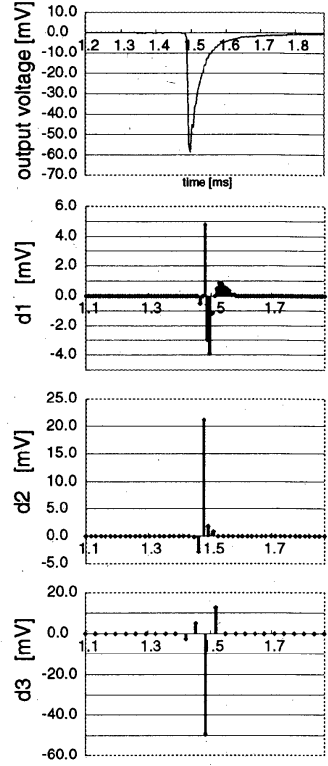

b) aluminum
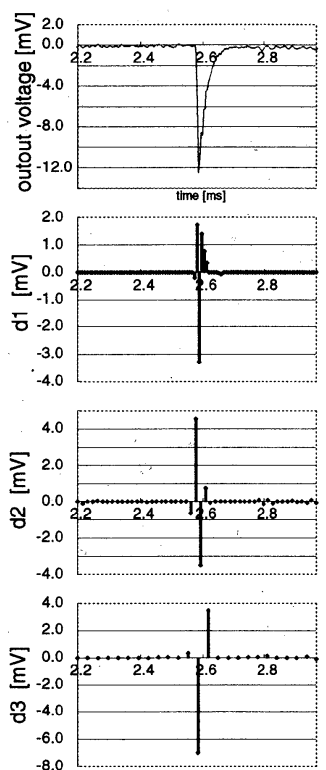

d) paper
Fig. 9 Discrete Wavelet Transform of the sensor outputs in the case of $\operatorname{Symlet}(\mathrm{N}=8)$ for various kinds of object surface

プラスチック，コピー用紙）を滑らせたときのセンサ出力信 号に対し, 離散ウェーブレット変換を行った結果である。こ の 4 つの場合のそれぞれに対して, 縦 4 つの図の横軸（時間 軸）は同じ夕イミングであり，1番上の図が変換対象である センサ出力信号で, 下 3 つの図はウエーブレット係数を示し, $\mathrm{d} 1, \mathrm{~d} 2, \mathrm{~d} 3$ の順に高周波成分から低周波成分を表している. 凸部単体の自由振動のウェーブレット変換結果と各滑り信 号を比較すると, まず, 各周波数成分の振幅が異なっている のは，もととなるセンサ信号自体の振幅の大きさに依存して いるからである.つぎに，同図 b) の $\mathrm{d} 1$ と $\mathrm{d} 2$ は，他のそれ と比べて波形が異なって見えるのは，立ち上がり時にわずか 
に曲率の低いところが見られること, そして, ピーク後の立 ち下り波形がやや急峻さに欠けることに起因している。しか しながら，各波形の主周波数成分を表す $\mathrm{d} 3$ はいずれも互い に似たパターンとなっており,これら 4 通りの波形がおよそ 等しいことが明らかとなった，すなわち以上より, 物体の滑 り時のセンサ信号は, 指紋凸部の自由振動を表す信号とおよ そ等しい, つまり, 自由振動によるものであると結言できる. そして, この高周波微振動が表面状態に依存せず, 固有の振 動を示すこともわかった.

つぎに, Fig.8のインパル ス状のセンサ出力値は一定でな く, それに加え出力間隔も一定とはなっていない点に着目す る. 本来, stick-slip 現象は, 接触部位である指紋凸部が付着 (stick) したままずれ，ずれが大きくなると開放されてもと に戻ろうとするときに滑る（slip）というものである.そこ で, Fig.8のそれぞれにおいて，1つ目のインパルス状信号出 力のときにセンサの指紋凸部が滑り, その次のセンサ出力ま では付着したままずれ，また滑りが生じていると考える．す ると, この stick-slip のプロセスにおいて, 付着したままX 軸方向のずれによって引き伸ばされるときの歪み量と, その 後滑りの瞬間に開放されてもとに戻ろうとするときの指紋凸 部の自由振動振幅は比例する. また, 本実験では一定の速度 で対象物体を X 軸方向に動かしているため, 付着時間と付着 による歪み量は比例する。よって, 付着時間とセンサ出力は 比例関係を示すと考えられることになる.

実際, 3 種の対象物体について, 付着から次の付着までの 間の時間間隔とその出力信号との関係を回帰分析したものを Fig.10に示す. それぞれの眓の左下には, 各回帰直線の決定 係数 $R^{2}$ を示した. 上記の仮説を裏付けるように, Fig.10で は, 決定係数 $R^{2}$ はいずれも 0.65 以上となっており, 付着時 間とセンサ出力とは高い相関，すなわち比例関倸にあること がわかった。したがって, センサ出力の間隔が一定にならな いのは, 物体表面が均質でなく, 指紋凸部の付着具合が表面 の場所によって異なるためだからであると言えることになる. このように, stick-slip 振動は表面状態に大きく依存する.

\section{4. 滑り以外の様々な接触状態に対する滑り覚セ ンサ出力の評価}

前節で説明づけられた指紋凸部の slip 時のふるまいに基づ き，本節では，さらに滑りに固有な情報を見極める。

\section{1 接触と開放の瞬間におけるセンサ出力}

ロボットフィンガによる物体の把持に移る局面の考え, 滑 り覚センサに対象物体を接触させる実験を行った. Z 軸ス テージを垂直に上昇させ, 接触したときの滑り覚センサの出 力を Fig.11に示す. 次に，把持した物体を放す瞬間を考え て, 先とは逆に Z 軸ステージを降下させたときのセンサ出力 をFig.12に示す.

まず, 対象物体に接触する瞬間のセンサ出力は, stick-slip 時のセンサ出力に対して非常に小さな値となっている。これ は，2.1節で述べたように，本センサでは PVDFフィルムト

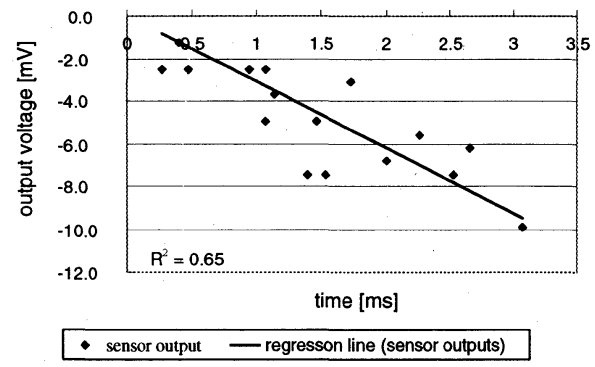

a) aluminum

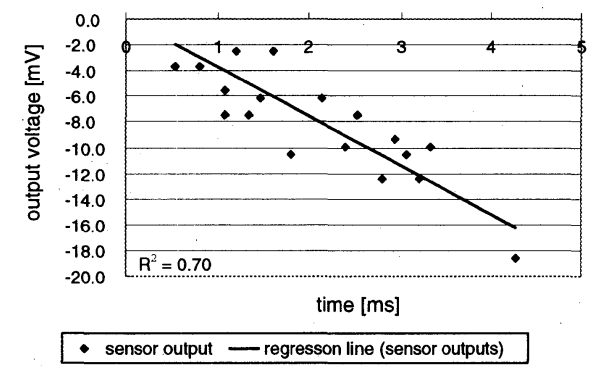

b) plastic

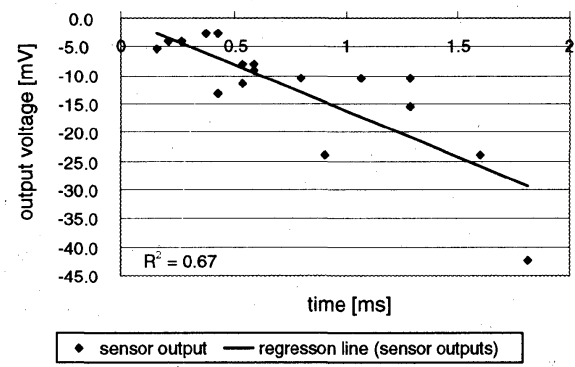

c) paper

Fig. 10 Correlation between the sensor outputs and the sticking interval

ランスデューサを立て置きにしていることから, 歪みの大き いX軸方向以外の方向への荷重に対する出力が小さいことに 起因している.

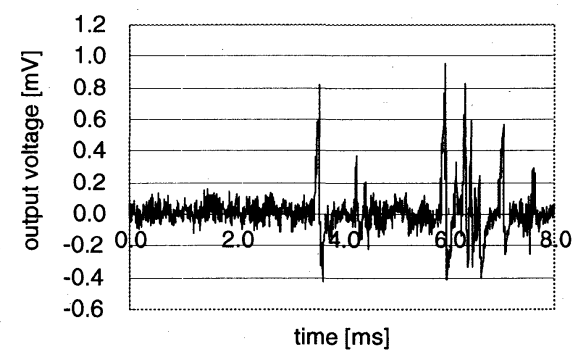

Fig. 11 Slip sensor output at the instant of the sensor making contact with the object

また，接触物体から離れる瞬間のセンサ出力の中には，と きにFig.12のように大きく, 凸部単体の自由振動とよく似た 波形の信号が現われることがある。これは, 滑り状態におけ

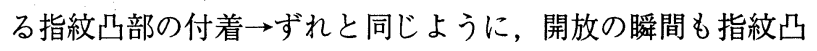
部が対象物体に付着し伸ばされ，歪みのエネルギが付着のエ 


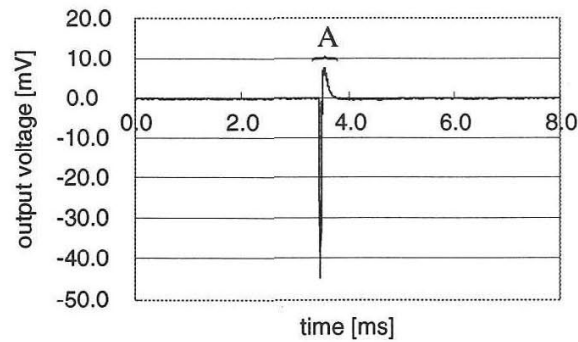

Fig. 12 Slip sensor output at the instant of the sensor breaking contact with the object

ネルギを超えたときに放たれるために出力されると考えられ る、しかしながら，この開放の瞬間のセンサ出力には，イン パルス状の信号のあとに戻り量（Fig.12 A 部）が現れる。こ の戻り量は，滑りのときには出力されないものであり，本研 究では開放時固有戻り量（release-phase overshoot）と定め る。この結果から，確かに指紋凸部が開放されて自由振動を していることがわかる。

以上より提案するセンサによれば，フィンガが物体と接触 する瞬間や，ロボットハンドが物体を開放する瞬間の出力と， 滑りによる出力とを明確に区別することができる。

\section{2 物体の把持局面における接触時のセンサ出力}

滑り覚センサは, シリコンゴムをべースとして作られてい るため, ハンドによる操りのときに物体の転がり状態が発生 することも考えられる。センサシステムとしては，センサの 出力がこの転がりによるものか, あるいは滑りに起因する stick-slipによるものかを，区別できなくてはならない，そ こで，センサ表面上で円筒形のアルミ製の円筒を転がした ときの，センサ出力を Fig.13に示す．この場合の出力には， Fig.12の対象物体とセンサが離れる場合と同様に，開放時固 有戻り量（Fig.13 B 部）が確認できる。これは，指紋凸部が 対象物体と接触しておらず，自由振動をしていることを示し ている.

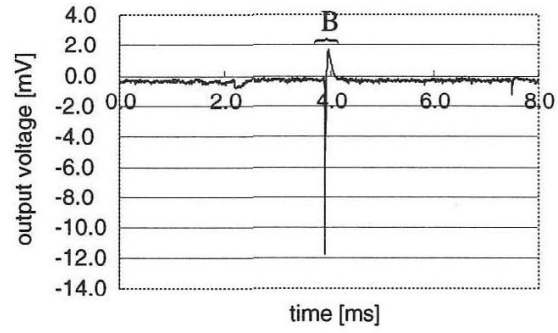

Fig. 13 Slip sensor output at the instant of the object rolling on the sensor surface

本節最後に，実際に物体を滑らせているときの，ロボッ トフインガ先端の力覚センサ出力に相当する 3 軸力覚セン サ（Fig.7）の Z 軸成分出力例を Fig.14に示す．実験条件は Fig.8の滑り実験と同様で，対象物体を $16 \mathrm{~mm} / \mathrm{s}$ でX 軸方向 に動かした。このときの $\mathrm{Z}$ 軸方向の押し付け力は, $0.75 \mathrm{kPa}$ である．同図信号の振動周波数の主成分は，X 軸ステージ駆 動時の主振動成分におよそ対応している。このように, フィ ンガなどに取り付けた力覚センサによって滑りをセンシング
しようとしても，モータ駆動時のノイズが重畳すると，微小 な力の変化である滑り振動出力だけを分離して捉えること は困難となる。一方，筆者らが提案するセンサは，たとえば Fig.8の結果からわかるように, stick-slip が起こらないかぎ り出力を出さない.これは, PVDFフィルムを垂直に設置し たことにより達成されており，その構造の有効性がここでも 明らかになった。

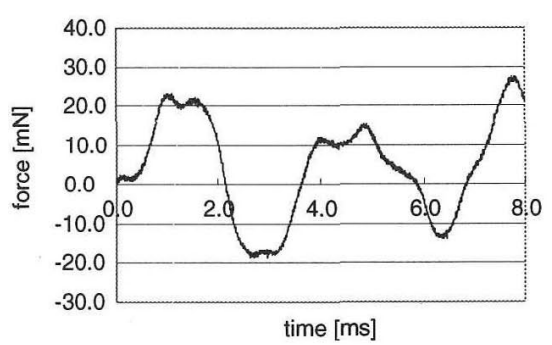

Fig. 14 Force sensor output at the instant of the sensor grasping an object

以上のように，提案する滑り振動覚センサは，ロボットフィ ンガによる安定把持と操りのときでも，明確に滑り振動を検 出することができる。

\section{5. 滑り覚センサの有用性の確認}

前節までに, 滑り覚センサそのものの挙動や機能の評価結 果を記述した。本節では，滑り覚センサを取付けたロボット ハンドによって物体を実際に把持させ，滑り覚情報に基づい た物体の滑り抑止制御実験を行うことにより，提案するセン サが有用であることを実験によって示す。

\section{1 有用性検証実験装置}

Fig.15に示すような，2 自由度平面形ロボットフィンガを 2 台対向させたハンドを製作し，その一方の先端には，針入 度 55 , 厚さ $10 \mathrm{~mm}$ のシリコンゲル層を設けて柔軟な被覆を 構成し，さらにその表面に，感度は向上させたが Fig.1と同 じ構造をもつ滑り覚センサを接着した。このハンドシステム に，対象物体として選定した大学ノートを把持させる実験を 行った。各フィンガは, リンク機構によって，その根元に取

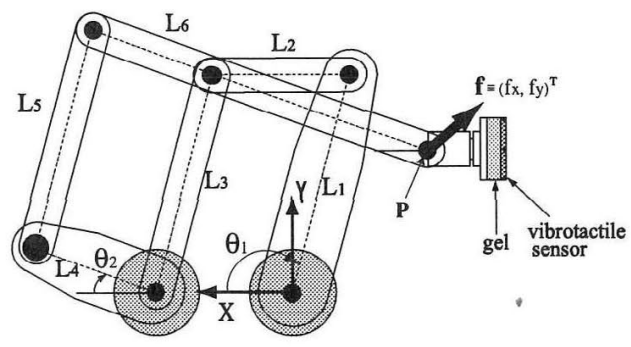

Fig. 15 Planar 3DOF finger with the sensor attached to the compliant endtip

付けた 2 個の DD モータへの指令トルク $\boldsymbol{\tau}=\left(\tau_{1}, \tau_{2}\right)^{T}$ によ り，同図に定義された $X Y$ 平面において点 $P$ に作用させる力 $\boldsymbol{f}=\left(f_{x}, f_{y}\right)^{T}$ を制御する。 


$$
f=\left(J^{T}\right)^{-1} \tau
$$

ただし，ロボットハンドの点Pにおけるヤコビ行列 $\boldsymbol{J}$ は，同図 中に定義されたリンクの長さやジョイントの角度を用いて，

$$
\boldsymbol{J}=\left[\begin{array}{cc}
-\left(L_{1}-L_{3}+L_{5}\right) \sin \theta_{1} & -\left(L_{4}-L_{6}\right) \sin \theta_{2} \\
\left(L_{1}-L_{3}+L_{5}\right) \cos \theta_{1} & \left(L_{4}-L_{6}\right) \cos \theta_{2}
\end{array}\right]
$$

と求められるものである.

まず，ノートの厚さ方向をハンドで把持している状態（後 揭 Fig.19参照）から，把握力を減小させて行くことにより発 生する滑りに伴って生じるセンサの 3 チャンネル出力の信号 変化を同時に捉えたグラフを Fig.16に示す．ハンドシステ

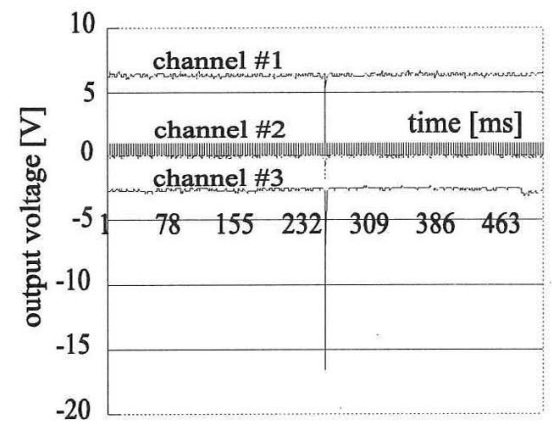

Fig. 16 Sonsor output signals of the three sensor elements: there is little difference of starting slipping instant

ムのサンプリングタイムは, $1 m s$ であり, 同図から，3つの 出力信号におけるインパル ス状信号がほぼ同時に現れ，それ らのタイミングのずれは，高々 $1 \mathrm{~ms}$ であることがわかった。

これまで，スティックスリップを検出するタイプの滑り覚 センサでは，滑りを検出する信号の発生タイミングが遅くな るために，実時間の把握制御には必ずしも適さないとして， Son ら 10)や Tremblay ら ${ }^{11)} は$ ，物体のセンサ表面全体にお ける滑り（total slip）を未然に防ぐアプローチとして，初 期局所滑り（incipient slip）情報が有用であるとする提案を 行っている.しかしながら, 柔らかい被覆を表面にもつハン ドでも，本研究の場合のように，センサ表面が平面的な形状 の場合には，全体の滑りに先駆けたタイミングの局所滑りが 必ずしも発生するわけではないため, 結局, 物体が落ち始め てから把握力制御を行わざるを得ないことを本実験結果は示 している.

\section{2 物体の滑り抑止制御}

前節 5.1 で述べた実験の初期状態から，徐々にハンドの把 握力を減小させて行き，ノートが落下を始めたときに生じる センサ出力信号に基づき，ノートの落下に間に合うようにハ ンドの把握力を調整するという滑り抑止制御を連続的に行っ た実験結果を Fig17に示す，同図は，センサチャンネル\#1 からの出力信号の変化をプロットしたもので, 上記の把握力 の再調整制御を $2 s$ の間に 4 回行ったものである. Fig17の期 間 Cをさらに拡大してプロットしたグラフを Fig.18に示す. $11 \mathrm{~ms}$ のうちの後半の $6 \mathrm{~ms}$ の間に, このハンドシステムは,

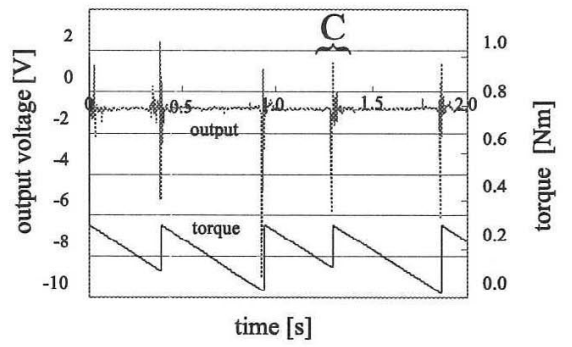

Fig. 17 Sensor output signal and correspondingly increased torque input during four repetitive phases of releasing and regripping the object

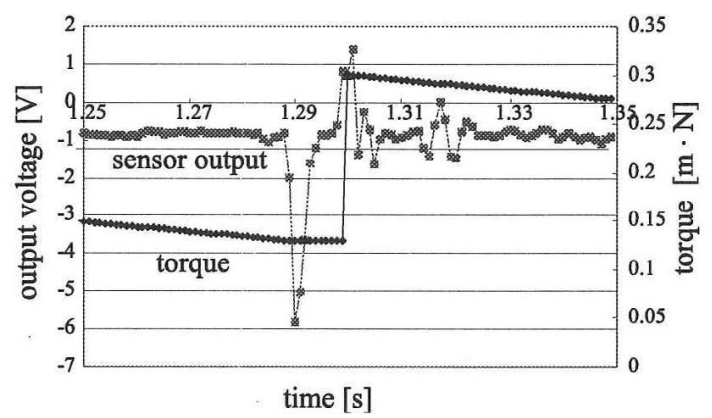

Fig. 18 Close observation of interval C in Figure 11

前節で定めた解放時固有戻り量が前半 $5 \mathrm{~ms}$ の滑り検出信号 に付随するか否かによって，この信号が確かに物体の滑りを 捉えているものであることを確認している，そして，その後， 物体の落下を抑止するための把握力再調整制御を行っている.

最㖟に，実験の様子を Fig.19に示す。この $2 s$ 間において， ノートの把持実験（把握力（圧力換算） $1.4 \mathrm{kPa}$ ）による落下 距離はわずか $4 m m$ ほどであり，滑り覚情報として，センサ 出力の高応答性が有効に利用できることが示された.

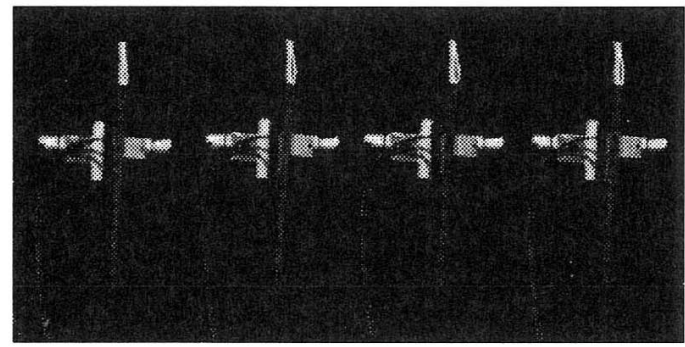

Fig. 19 Sequences of photographs of demonstrating the realtime object regrip control. The notebook slips down only $1 \mathrm{~mm}$ on average in a control cycle

\section{6.おわりに}

本論文では，ロボットフィンガの柔軟被覆表面の凹凸と把 持物体との間で発生する高周波滑り振動に着目し，物体の滑 り状態だけを検出することができる滑り覚センサを新たに提 案した。本研究において得られた結果を以下にまとめる.

（1）柔軟被覆の上にPVDF フィルムを縦置きにして，薄 
いゴム膜によって覆う凹凸状の指紋をセンサ表面に構成す る提案を行い, 実際に作成したセンサの構造とセンサ回路 を示した。

(2) 提案するセンサによって，その表面を物体が滑る際に 生じる高周波微振動が検出できることを示し, これが従来 の stick-slip 振動ではなく, 指紋部の薄い凸部の自由振動 によるものであることをウェーブレット解析により示した， さらに, stick-slip 振動が表面状態に依存するのに対し, 高 周波微振動は表面状態に依存しないことを示した.

(3) 従来の滑り覚センサでは, 評価されなかった重要な視 点として, 滑り状態を含むセンサ表面と物体間の様々な接 触状態に対するセンサ出力を評価し, 以下 3 点の実験結果 に基づく本センサ出力の特徽を明らかにした。

(3-1) 提案するセンサは, 接触の瞬間において, 滑ってい るときのセンサ出力と大きく異なった出力を示すため, 接 触の瞬間と滑り状態とを明確に識別できることを確認した。

（3-2）また, 物体のセンサ表面からの開放の瞬間とセンサ 表面における転がりのときは，滑り状態には発生しない開 放時固有戻り量（release-phase overshoot）が現われれる ことを発見し、これにより, 開放の瞬間または転がり状態 と滑り状態とを明確に識別できることを確認した。

(3-3) さらに, 力覚センサには駆動部モー夕による振動， イズが重畳することが実際に示されたのに対して, 提案す るセンサの場合では原理的にノイズが重胃しないことを示 した.

（4）最後に，提案するセンサを対向するロボットフィンガ の片側に取り付けたハンドを用いてノートを把持させ，そ の滑り抑止制御を達成することにより，提案するセンサの 有用性を実験的に示した。 その際, センサ出力から, 確か に物体の滑りを識別検出していることをチェックした後, ハンドの把握力を再調整するという制御プロセスをとった にも拘わらず，1回の滑りあたり， $1 \mathrm{~mm}$ の落下だけにとど まることがわかり，センサ出力の高応答性が滑り抑止制御 に有効に利用できることが示された。

本論文で提案するセンサによる滑り検出の高信頼化なら びに広範な応用途への実用化という観点から, 様々な対象物 の把持局面に対して，より詳細に指紋凸部の力学的挙動を調 ベながらセンサ出力を評価することは重要であると筆者らは 考えている.今後, センサ表面の凹凸の配置や適正なダウン サイズ化, さらに多次元化の問題と併せて上記内容を検討し ていきたい.

最後に, 本研究の一部は, 平成 $10 \sim 11$ 年文部省科学研究 費補助金（課題番号 10450161）により達成されたことを記 し，謝意に代えさせて頂きます。

\section{参 考 文 献}

1) M. Ueda et al. : Tactile Sensors for Industrial Robot to Detect A Slip, Proc. 2nd ISIR, 63/76 (1972)

2) 山田陽滋：把握までのセンシング戦略 その 2 : 滑りと静摩 擦係数の検出〜表面粗さ情報の取得, 日本ロボット学会誌,
11-7, 959/965 (1993)

3) 山田陽滋, 三田 賢志, 藤田和秀, 土田縫夫, 今井孝二 : 把握 力制御のための静止摩擦係数のアクティブ.センシング, 計測 自動制御学会論文集，30-10,1188/1194 (1994)

4) R.D.Howe and M.R.Cutkosky : Sensing Skin Acceleration for Slip and Texture Perception, Proc. IEEE Int. Conf. Robot. Automat., 145/160 (1989)

5) B. Eberman and J. Kenneth Salisbury, Jr. : Application of Change Detection to Dynamic Contact Sensing, MIT AI-memo No. 1421 (1993)

6）深堀美英：ゴム摩耗における摩擦（振動）と破壊のリンケー ジ，日本ゴム学会誌，68，605/618 (1995)

7）森田裕之, 山田陽滋, 梅谷陽二：ロボットハンドのための指紋 を備えた滑り振動覚センサ, 第 3 回ロボティクスシンポジア予 稿集, 89/94 (1998)

8) P. Dario, C. Domenici, R. Bardelli, D. De Rossi and P. C. Pinotti : Piezoelectric Polymers: New Sensor Materials for Robotic Applications, Proc. of 13th Int. Symp. on Industrial Robots and ROBOTS 7, Chicago, 2, 14-34/14-49 (1983)

9) Robert D. Howe and Mark R. Cutkosky : Dynamic Tactile Sensing: Perception of Fine Surface Features with Stress Rate Sensing, IEEE Trans. on Robotics and Automation, 9-2, 140/151 (1993)

10) J. S. Son, A. Monteverde and R. D. Howe: A Tactile Sensor for Localizing Transient Events in Manipulation, Proc. Int. Conf. on Robotics and Automation, 471/476 (1994)

11) M. Tremblay et al., Utilizing Sensed Incipient Slip Signals for Grasp Force Control, Proc. Japan-USA Symp. on Flexible Autom, 1237/1243 (1992)

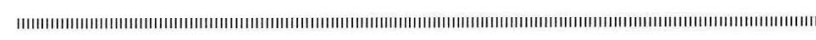

$$
\text { [著 者 紹 介] }
$$

山田陽滋

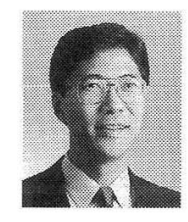

1983 年名古屋大学工学研究科修士課程修了. 同 年より豊田工業大学助手勤務. 93 年助教授. 同 年, Stanford University 客員研究員. 工学博士. ロボットのセンサ, 通信, 知能システムの研究に 従事. 日本ロボット学会, 日本機械学会, IEEE の会員.

\section{森田裕之}

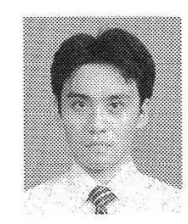

1999 年豊田工業大学大学院工学研究科修士課 程修了。同年, (株) デンソー入社. 現在に至る. 修士課程では, ロボットハンドのセンサベースト コントロールの研究に従事した。

\section{梅 谷 陽 二（正会員）}

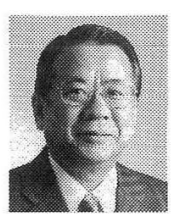

1956 年京都大学工学部機械工学科修士課程修 了. 56 年東京大学生産技術研究所助手, 講師. 70 年東京工業大学工学部助教授, 教授. 93 年豊田工 業大学教授 現在に至る. 工学博士. 自動制御, バイオメカニクス，ロボティクスの研究に従事. 人間と協調・共存できるロボット, 宇宙ロボット などに興味を持つ。日本ロボット学会名誉会員.

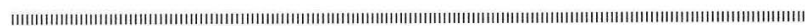

